\title{
Effects of Health Education on Knowledge and Attitude of the Health Cadres in Prevention of HIV, Diabetes, and Stroke
}

\author{
Cecep Eli Kosasih ${ }^{1}{ }^{*}$; Tetti Solehati ${ }^{2}$; Mamat Lukman ${ }^{3}$ \\ ${ }^{1}$ *) Department of Medical Surgical, Faculty of Nursing, Universitas Padjajaran, Indonesia \\ 2 Department of Maternity, Faculty of Nursing, Universitas Padjajaran, Indonesia \\ 3 Department of Community, Faculty of Nursing, Universitas Padjajaran, Indonesia

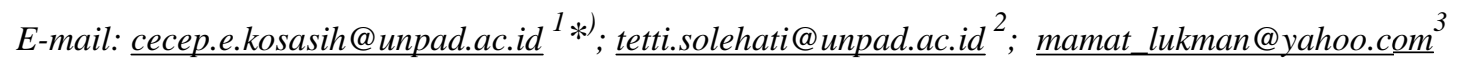

\section{ARTICLE INFO}

Article history:

Received January 21, 2019

Revised February 28, 2019

Accepted March 1, 2019

\section{Keyword:}

Diabetes

Health Education

HIV/AIDS

Stroke

\section{*) corresponding author}

DOI:http://doi.org/10.30604/jika.v4i1.168

\begin{abstract}
A B S T R A C T
Pangandaran is one of tourist destinations in West Java which is visited by foreign and domestic tourists that makes Pangandaran is vulnerable for infectious diseases such as HIV/AIDS. In addition, unhealthy lifestyles due to increasing of economic value in this area caused an increasing the risk of diabetes mellitus and stroke. Efforts to overcome the problem of infectious diseases caused by Diabetes, Stroke, and HIV AIDS, it required the support of various parties both from the health service center and from community participation, especially the role of cadres who are members of Integrated Healthcare Post (Posyandu). The study aimed to know the effect of health education on knowledge and attitude of the health cadres in prevention of HIV, diabetes mellitus, and stroke. The study was conducted in Pamotan and Bagolo Villages of Pangandaran Regency in 2017. The populations in this study were all health cadres of Posyandu in the two villages with 39 total sampling. Design of the study was quasi experimental with pretest and posttest design. Instruments used questioners. Data analysis used univariate and bivariate analysis. The results showed that there were significant higher of the mean scores about knowledge after intervention of DM (M 3.79), Stroke $(M=4.64)$, and HIV $(M=3.92)$, than before intervention DM $(M=3.15)$, Stroke $(M=3.26), H I V(M=2.85)$ $(p=0.00)$. There were significant higher of the mean scores about attitude after intervention of DM (16.46), Stroke (18.15), $H I V(18.51)$, than before intervention of DM $(M=15.13)$, Stroke $(M=15.36)$, and HIV $(M=15.64)(p=0.00)$. In this study, there were significantly different of mean scores of knowledge and attitude of health cadres before and after intervention period. It can be suggested for nurses that this method could increase a health promotion especially to increase knowledge and attitude of the cadres.
\end{abstract}

This is an open access article under the CC-BY-SA license. 


\section{BACKGROUND}

The Indonesian government is intensively promoting public health efforts to prevent communicable and non-communicable diseases. Infectious diseases, one of them is HIV (Human Immunodeficiency Virus) / AIDS (Acquired Immuno Deficiency Syndrome) which every year has increased. This disease causes the patient's immune system becomes weak and susceptible to various diseases. Among all people who infected with HIV, some developed into AIDS in the first three years, $50 \%$ became AIDS after ten years, and nearly $100 \%$ of HIV patients showed symptoms of AIDS after 13 years (Ardhiyanti, Lusiana, \& Megasari, 2015). The number of new AIDS cases were 9,649 (2012), 10,163 (2013), and 5,494 (2014). Cumulative AIDS cases until 2014 amounted to 65,790 cases (Ministry of Health, 2015). The data is an iceberg phenomenon. New AIDS symptoms appeared after 3 - 10 years of infection. Thus, it was likely that most of those affected by AIDS have been infected at a younger age.

HIV/AIDS is at high risk of transmitting to tourist areas. Pangandaran is one of the areas prone to HIV/AIDS transmission. Considering its location is one of the tourist attractions in West Java, which is visited by foreign and domestic tourists. The mobilization of residents and visitors in the Pangandaran tourist area made Pangandaran District vulnerable to the spread of infectious diseases (Prasetyowati, Marina, Widawati, \& Wahono, 2014). In this area there were many people including mothers who were less knowledgeable about the mode of transmission and prevention of HIV AIDS. This fact would increase the number of HIVinfected women who it could transmit to their babies when the mother was pregnant.

According to Matahari Jabar Foundation Coordinator, the number of HIV in Pangandaran Regency as many as 45 suffered by fishermen, pregnant women, married couples, sex workers, and four-year-old toddlers. This is an iceberg phenomenon where the actual number is probably much larger than that number. Therefore, it was necessary to conduct HIV/AIDS prevention activities, according to (Ministry of Health, 2015) such activity consisted of health promotion, prevention of HIV transmission, HIV diagnostic examination, treatment, care and support, and rehabilitation (Ministry of Health, 2013). There is important for increasing the knowledge and attitudes to prevent the spread of HIV/AIDS, especially in rural areas because of the difficulty of accessing the information they obtain.

According to (SDKI, 2012), the knowledge on how HIV prevention was higher in women who live $(45 \%)$ in urban areas than those who live in rural areas (28\%). Provision of education about prevention of HIV/AIDS community is important given due to the lack of knowledge and attitudes. Data from Riskesdas (Basic Health Research) showed that more than half of the population knew how to spread HIV through unsafe sexual intercourse and shared needle syringe $(51.4 \%)$, and knowing the mode of transmission through unsafe blood transfusions (46.6\%) (Ministry of Health, 2010). The percentage of people who knew that HIV/AIDS could be transmitted from mother to child during pregnancy were $38.1 \%$, during delivery $(39.0 \%)$ and while breast-feeding was (37.4\%). People who know proper prevention by way of sexual intercourse with only one fixed partner who was not at risk (49.4\%), HIV could be prevented by sexual intercourse with husband/wife only (50.3\%); HIV could be prevented by not having sexual intercourse at all $(36.9 \%)$, that HIV could be prevented by using condoms (41.9\%). HIV could be prevented by not sharing a shared needle (44.9\%) and knowing that HIV could not be prevented by circumcision $(21.8 \%)$.

Other problems that arise in the Pangandaran area were non-infectious diseases caused by their poor healthy lifestyles, such as unhealthy behaviors that could increase stroke and diabetes mellitus (DM). 
According to data from interviews with Pamotan Village Head on December 2016 found the incidence of stroke more and more, also the incidence of DM increased, but they did not have a descendant of DM. The village head said he was confused by the phenomenon and needed a competent person who could socialize to the community to solve the problem. Stroke and diabetes mellitus is a non-communicable disease that is increasing in Indonesia. Data from Basic Health research, 2013 showed that there was an increased prevalence of stroke from 8.3 per1000 (2007) to 12.1 per1000 (Ministry of Health, 2013). Similarly, Diabetes mellitus increased from $1.1 \%$ (2007) to $2.1 \%$ (2013) (Ministry of Health, 2015).

Stroke is a disease in which the loss of brain function caused by the cessation of blood supply to the brain (Smeltzer, Bare, Hinkle, \& Cheever, 2010). The main risk factors for stroke included hypertension, cardiovascular disease, diabetes mellitus, TIA (Transient Ischemic attack), high blood fat levels, and others. Complications of stroke included cerebral hypoxia, decreased cerebral blood flow, causing brain tissue death. Stroke causes a person to become helpless in performing their daily needs which can lead to a decrease in the quality of their lives. In addition, other non-infectious diseases that can cause decreased quality of life is DM.

Diabetes is a group of metabolic diseases characterized by hyperglycemia due to insulin secretion defects, insulin action, or both (American Diabetes Association, 2010). Most of the DM would occur in developing countries in the age group of 45-64 years due to population growth, aging, unhealthy diet, obesity and less physical activity (World Health Organization, 2002). This also happened in Indonesia which was one of the developing countries (Aini, Fatmaningrum, \& Yusuf, 2011) stated that DM treatment took a long time to be suffered for life, and was very complex because it not only required treatment but also lifestyle changes so that often patients tended to become discouraged by the therapy program. Such circumstances may affect the physical, psychological and social functional capacity and well-being of people with diabetes mellitus defined as quality of life (QOL). A study conducted in Palestine found that all domains were physical health domains (36.7 vs. 75.9 from $0-100$ score ranges), psychological domains (34.8 vs. 70.0), the domain of social relations (52.4 vs. 71.4 ) and the environmental domain (23.4 vs. 36.2$)$ of DM patients experienced considerable decrease compared to the quality of life of normal populations as a control group (Eljedi, Mikolajczyk, Kraemer, \& Laaser, 2006). To prevent the occurrence of HIV/AIDS, stroke, and DM was needed an effective effort in preventing the occurrence of the disease.

The Government of Indonesia has formulated several policies to support the improvement of health in the community by establishing a community-based service called Posyandu. Posyandu is one of the approaches of community participation in health sector managed by health cadres of Posyandu where they have received education and training from Public Health Center (Puskesmas). Posyandu health cadres are a form of community participation and an extension of health workers. They are needed considering the limited number of health workers. Their role is very important because it is a health provider near the target activity, having frequent cadre face-to-face compared to other health workers, it is one of the role models for local people. Unfortunately, according to health cadres and village officials, many health programs have not been presented to them, such as how to prevent HIV / AIDS transmission, stroke prevention and DM.

Based on the above problem, education program is needed to increase knowledge and attitude of health cadres Posyandu by training on prevention program of HIV/AIDS, training on prevention program of stroke, training on DM disease prevention program. The study aimed to know the effect of health 
education on knowledge and attitude of the health cadres in prevention of HIV, diabetes mellitus, and stroke.

\section{METHOD}

Quasi experimental research design was applied with pre test and post test design. The data collection was conducted in Bagolo and Pamotan Village, Kalipucang District, Pangandaran Regency in 2017. The population in this research was all health cadres of Posyandu in both villages totaling 39 people. Inclusion criteria included: health cadres in Bagolo and Pamotan villages, they were adult (aged 18 and more), experienced as cadre at least one year, willing to participate in this study. The sample used was total sampling. The All Posyandu health cadres were given questioners on HIV/AIDS, stroke, and DM before and after intervention. These questioners were provided to measure the level of knowledge and attitude. The intervention in this study was a health education program using interactive health education method (with Focus Group Discussion, using video and photographs of HIV/AIDS, stroke, and DM). A t-test was used to analyze the effect of education program on level of knowledge and attitude.

\section{RESULT AND DISCUSSION}

\section{Average Level of Knowledge of the health cadres}

Before the training, health cadres performed pre tests on knowledge and attitudes related to Diabetes, Stroke, and HIV/AIDS. The results obtained from the pretest evaluation (before the intervention) can be seen in Table 1.

Table 1. Mean of Knowledge of the health cadres before and after intervention $(n=$ 39)

\begin{tabular}{lcccc}
\hline \multirow{2}{*}{ Variables } & \multicolumn{4}{c}{ Groups } \\
\cline { 2 - 5 } & \multicolumn{2}{c}{ Pre intervention } & \multicolumn{2}{c}{ Post intervention } \\
\cline { 2 - 5 } & Mean & $S D$ & Mean & $S D$ \\
\hline DM & 3.15 & 0.961 & 3.79 & 0.409 \\
Stroke & 3.26 & 1.019 & 4.64 & 0.668 \\
HIV & 2.85 & 0.904 & 3.92 & 0.354 \\
\hline
\end{tabular}

Table 1 showed that there were increasing mean of knowledge about DM (3.15), Stroke (3.26), and HIV (2.85) before intervention, into DM (3.79), Stroke (4.64), and HIV (3.92) after intervention.

This showed that education had significant role in improving knowledge. Increased knowledge occurred because the education was done which delivered using two-way methods and reinforced by related photographs and question and answer were attractive, and strengthened by the facilitators who stimulated respondents to ask and answer. In addition, all the respondents were active cadres who managed Posyandu in their respective areas and had a high sense of curiosity in knowing something of the health sciences, because they were always involved in things that they usually found. In terms of age, most of Posyandu health cadres were at a young age (productive aged) and had the motivation to improve themselves both science and work achievement of this matter that encouraged them to keep learning.

Table 2.

Mean comparison of knowledge between before and after intervention among health cadres $(\mathbf{n}=39)$

\begin{tabular}{lcccc}
\hline \multicolumn{1}{c}{ Comparison } & $\begin{array}{c}\text { Mean } \\
\text { difference }\end{array}$ & $t$ & $d f$ & $p$ \\
\hline Knowledge of DM pre - post intervention & -0.641 & -4.058 & 38 & .000 \\
Knowledge stroke pre - post intervention & -1.385 & -6.229 & 38 & .000 \\
Knowledge HIV pre - post intervention & -1.077 & -6.837 & 38 & .000 \\
\hline
\end{tabular}


Table 2 showed that there were significant difference of knowledge about DM between pre-intervention and post-intervention $(t=$ 4.058, $p=.000)$. There were significant difference in knowledge about stroke between pre-intervention and postintervention $(t=-6.29, p=.000)$. There were significant difference in knowledge about HIV between pre-intervention and postintervention $(t=-6.837, p=.000)$.

This showed that there was an effect of health education provided by the researcher on increasing the mean level of knowledge of health cadres of Posyandu. The results of the study were in line with (Kishore et al., 2008) in his research on 593 respondents in Delhi to prove that health education had an effect on the increase of respondents' knowledge. In addition, to the increased knowledge, education provided by researchers also improved the attitude of health cadres.
Mean of attitude of the health cadres

Table 3. Mean of attitude of the health cadres before and after intervention $(n=39)$

\begin{tabular}{|c|c|c|c|c|}
\hline \multirow{3}{*}{ Variables } & \multicolumn{4}{|c|}{ Groups } \\
\hline & \multicolumn{2}{|c|}{ Pre intervention } & \multicolumn{2}{|c|}{$\begin{array}{c}\text { Post } \\
\text { intervention }\end{array}$} \\
\hline & Mean & $S D$ & Mean & $S D$ \\
\hline DM & 15.13 & 1.853 & 16.46 & 1.714 \\
\hline Stroke & 15.36 & 1.769 & 18.15 & 1.770 \\
\hline HIV & 15.64 & 2.121 & 18.51 & 1.745 \\
\hline
\end{tabular}

From the Table 3 above showed that there were increasing mean of attitude about DM (15.13), Stroke (15.36), and HIV (15.64) before intervention, into DM (16.46), Stroke (18.15), and HIV (18.51) after intervention in health cadres of Posyandu. This showed that education played significant role in improving the attitudes.

Table 4. Mean comparison of attitude between before intervention and after intervention among health cadres $(\mathbf{n}=39)$

\begin{tabular}{lcccc}
\hline \multicolumn{1}{c}{ Comparison } & $\begin{array}{c}\text { Mean } \\
\text { difference }\end{array}$ & $t$ & $d f$ & $p$ \\
\hline Attitude DM pre - post intervention & -1.333 & -5.391 & 38 & .001 \\
Attitude stroke pre - post intervention & -2.795 & -13.625 & 38 & .001 \\
Attitude HIV pre - post intervention & -2.872 & -12.652 & 38 & .001 \\
\hline
\end{tabular}

Table 4 showed that there were significant differences in attitude about DM between pre-intervention and post-intervention $(t=-$ 5.391, $p=.001)$. There were significant differences in attitude about stroke between pre-intervention and post-intervention $(t=-$ $13.625, p=.001)$. There were significant difference in HIV attitudes between preintervention and post-intervention $(t=$ $12.652, p=.001)$.

This showed that education affected to the level of knowledge also affected the attitude of health cadres. Education could change the way a person thinks that affected his attitude. The results of the study was in line with (Salem, Balahmar, Milaat, \& Gabal, 1999) in his study of 148 health care workers in Jeddah Saudi Arabia showed that the training had significant effected on the knowledge, attitude and practice of the health care workers $(p<0.001)$. Similarly with (Abiola et al., 2013) who conducted a study on 104 nursing students in Nigeria concluded that education had significant impacted on knowledge and attitudes of respondents.

Some of the factors driving the success of education in improving the level of knowledge and attitude of health cadres in Pamotan Village and Bagolo Village were good acceptors from local government, subdistrict head, village head, head of Puskesmas, and local community leaders. Besides, the officer of the village would listen and receive the input from the activities that had been done. So, the village always 
supported both material and administrative support.

Knowledge and behavior of health cadres will influence their behavior patterns in influencing and supporting the community about the importance of healthy lifestyle in preventing HIV/AIDS, stroke, and diabetes. With sufficient knowledge and attitudes that support a healthy lifestyle, health cadres will confident in disseminating the information and in addressing health issues to the communities in their territory.

Posyandu health cadres as an extension of health personnel have a significant role in providing public health information and in supporting the behavior of public health in their region. Their role is very important because they has more time to contact with the surrounding community. Healthcare cadres are important in providing health information and conducting social support to the patients and their families in the surrounding community for the patient's healing process. Healthcare cadres with adequate knowledge and attitudes can teach and support families with HIV/AIDS, DM, and stroke patients, and also supporting the family member. According to (Rahmawati, Setiawati, \& Solehati, 2015) in 50 patients of DM in Jatinangor Sumedang found that family support affected the quality of life of DM patients. DM patients, stroke, and HIV required social support, both from the family and the surrounding community. A study proved that social support positively affected to the psychological health, physical wellbeing, and quality of life (Tough, Siegrist, \& Fekete, 2017).

\section{CONCLUSION AND RECOMMENDATION}

In this study found that training could increase knowledge and improve the attitude support of Posyandu health cadres on prevention of HIV/AIDS, diabetes, and stroke in the health cadres of Pamotan and Bagolo Villages, Pangandaran Regency.
Training, counseling, or other forms of refreshing is necessary for cadres in updating their knowledge that so far they has been only focused on Posyandu only. This training is better not only limited to material on the prevention of diabetes, stroke, and HIV/AIDS alone but also related material to other matters where the need for increased knowledge is required on various aspects because so far they are faced with the problems that they itself needs to get help. To achieve the success of diabetes control program, prevention of stroke, and prevention of HIV/AIDS transmission, coordination from related parties is needed. The main parties are Puskesmas and village government. Therefore, it needs the real steps to encourage health cadres in the village area can run well and continuously. Health cadres as the spearhead of basic services in the village becomes important if the implementation of Posyandu can run well. To be continuous, things to consider are support from the Puskesmas in the form of knowledge and operational support, while from the village government in the form of policy and operational support.

\section{ACKNOWLEDGMENT}

Our thanks go to the Director General of Research and Technology and Director of DRPMI Padjadjaran University who have funded this research and to all parties who have participated in the completion of this study. 


\section{BIBLIOGRAPHY}

Abiola, A. O., Ojika, B. O., Mannir, B., Abba, S. K., Muhammad, M., Ibrahim, M. T., . . . Akanmu, S. S. (2013). Effect of health education on the knowledge and attitude to sickle cell disorder and screening practices among school of nursing students in Sokoto, Nigeria. Nig $Q$ J Hosp Med, 23(1), 65-68. Retrieve: https://www.ncbi.nlm.nih.gov/pubmed/ 24579498. journal article: https://www.ajol.info/index.php/nqjhm /article/view/177152

Aini, N., Fatmaningrum, W., \& Yusuf, A. (2011). Upaya meningkatkan perilaku pasien dalam tatalaksana diabetes mellitus dengan pendekatan teori model behavioral system Dorothy E. Johnson. Jurnal Ners, 6(1), 1-10. https://doi.org/10.20473/jn.v6i1.3960

Retrieve: https://ejournal.unair.ac.id/JNERS/article/view 13960

American Diabetes Association. (2010). Diagnosis and classification of diabetes mellitus. Diabetes care, 33(Supplement 1), S62-S69. https://doi.org/10.2337/dc14-S081

Retrieve:

http://care.diabetesjournals.org/content 137/Supplement_1/S81

Ardhiyanti, Y., Lusiana, N., \& Megasari, K. (2015). Bahan ajar AIDS pada asuhan kebidanan: Deepublish. Retrieve: https://books.google.co.id/books?hl=en $\& 1 \mathrm{r}=\& \mathrm{id}=\mathrm{CD} 9 \mathrm{yDwAAQBAJ} \&$ oi=fnd \&pg=PT5\&dq=info:zpYRe j05dkJ:sch olar.google.com\&ots $=8$ PEibRSOsW\& sig=eN1eiyqGP6h7CeukWwJGJo49pj $\underline{0 \& \text { redir_esc }=\mathrm{y} \# \mathrm{v}=\text { onepage } \& \mathrm{q} \& \mathrm{f}=\text { false }}$

Eljedi, A., Mikolajczyk, R. T., Kraemer, A., \& Laaser, U. (2006). Health-related quality of life in diabetic patients and controls without diabetes in refugee camps in the Gaza strip: a cross- sectional study. [Research Support, Non-U.S. Gov't]. BMC Public Health, 6, 268. https://doi.org/10.1186/14712458-6-268

Kishore, J., Gupta, V. K., Singh, S. V., Garg, S., Kaur, R., \& Ingle, G. K. (2008). Impact of health education intervention on knowledge and community action for malaria control in Delhi. $J$ Commun Dis, 40(3), 183-192. Retrieve:

https://www.ncbi.nlm.nih.gov/pubmed/ 19245156

Ministry of Health, M. (2010). Laporan Riset Kesehatan Dasar (Riskesdas) 2010 Bidang Biomedis. Jakarta: Badan Litbangkes, Depkes RI, 10(4), 5. Retrieve:

http://kesga.kemkes.go.id/images/pedo man/Riskesdas\%202010\%20Nasional. $\underline{\mathrm{pdf}}$

Ministry of Health, M. (2013). Survei demografi dan kesehatan Indonesia 2012. Jakarta: Kementrian Kesehatan $R I$.

Retrieve: http://www.depkes.go.id/resources/do wnload/pusdatin/profil-kesehatanindonesia/Indonesia\%20Health\%20Pro file $\% 202013 \% 20$ \%20v2\%20untuk\%20web.pdf

Ministry of Health, M. (2015). Data dan Informasi Tahun 2014 (Profil Kesehatan Indonesia). Jakarta: Kementerian Kesehatan Republik Indonesia.

Prasetyowati, H., Marina, R., Widawati, M., \& Wahono, T. (2014). Survey jentik dan aktifitas nokturnal Aedes spp. di Pasar Wisata Pangandaran. Indonesian Journal of Health Ecology, 13(1), 33https://doi.org/42.10.22435/jek.v13i1 Mar.3940 http://ejournal.litbang.depkes.go.id/ind ex.php/jek/article/view/3940 
Rahmawati, F., Setiawati, E. P., \& Solehati, T. (2015). A literature review: The effect of family support on quality of life of patients with type 2 diabetes mellitus. Proceeding 3rd International Nursing Conference 2015. , 2015, from https://core.ac.uk/download/pdf/76930 906.pdf

Salem, K. A., Balahmar, M. K., Milaat, W., \& Gabal, M. S. (1999). The Effects of a Training Program on Knowledge, Attitude and Practice of The Staff of Primary Health Care Centers Towards Growth Monitoring: an Intervention Study. [Evaluation Studies]. J Egypt Public Health Assoc, 74(5-6), 627-649. Retrieve:

https://www.ncbi.nlm.nih.gov/pubmed/ $\underline{17219866}$

Smeltzer, S. C., Bare, B. G., Hinkle, J. L., \& Cheever, K. H. (2010). Brunner \&
Suddarth's Textbook of Medicalsurgical Nursing (Vol. 1): Lippincott Williams \& Wilkins. Retrieve: https://books.google.co.id/books/about /Brunner_Suddarth_s_Textbook_of_M edical_s.html?id=SmtjSD1x688C\&red ir_esc $=\mathrm{y}$

Tough, H., Siegrist, J., \& Fekete, C. (2017). Social relationships, mental health and wellbeing in physical disability: a systematic review. BMC Public Health, 17(1), 414-414. https://doi.org/10.1186/s12889-0174308-6

World Health Organization. (2002). Diabetes mellitus fact sheet no. 138. World Health Organization, Geneva, Switzerland. Retrieve: https://www.who.int/nmh/publications/ ncd_report_full_en.pdf?ua $=1$ 